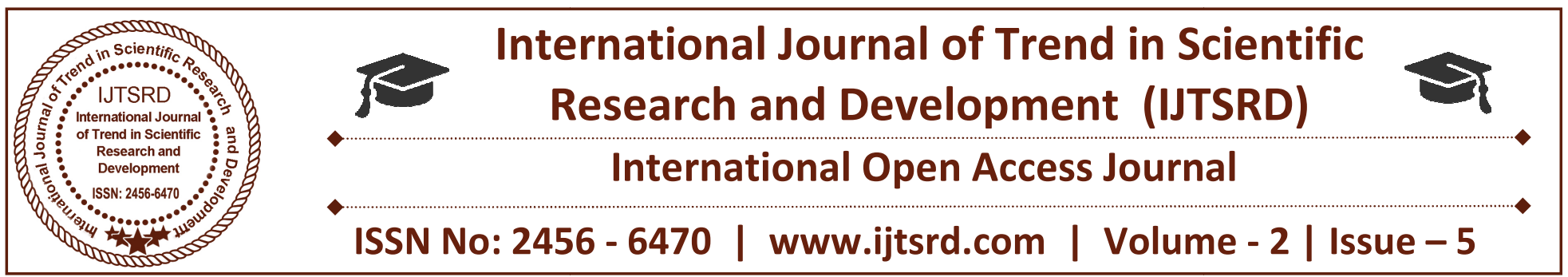

\title{
Role of Corporate Culture in Foreign Market Access
}

\author{
Samidha Sengupta \\ Student, Indore Institute Of Law, \\ Rau Pithampur Road, Opp. IIM, Indore, Madhya Pradesh, India
}

\section{ABSTRACT}

The paper examines the impact of corporate culture in foreign market access. The paper talks about that what a corporate culture is, Corporate culture refers to the beliefs and behaviours that determine how a company's employees and management interact and handle outside business transactions. The history of corporate culture that how the culture came into light, The term corporate culture created in the mid1980s and turned out to be broadly known by the 1990s. then what is organisational culture, Organizational culture is defined as the underlying beliefs, assumptions, values and ways of interacting that contribute to the unique social and psychological environment of an organization. The characteristics of corporate culture. How a corporate culture works in a small business, Corporate culture should convey how the business sets expectations and rewards desired behaviours. Then the paper talks of effects of globalization in corporate culture, The "new" in new economy means a more stable and longer growth, with more jobs, lower inflation and interest rates, explosion of free markets worldwide, the unparalleled access to knowledge through the Internet and new type of organization which affects organizational change. Then the paper shows that different market access of different countries. Then the paper talks about the India-china market access and trade relations, India China exchange relations are the most essential piece of reciprocal relations amongst India and China. The essential things of Indian fares to China are minerals, slag and fiery debris, iron and steel, plastics, natural synthetic concoctions, and cotton. Lastly the paper talks about that if is it profitable for a country to allow foreign market access, As every coin has two sides, it can be said that foreign market access is profitable but it should in a limit.
Keywords: corporate culture, small business, market access

\section{CORPORATE CULTURE}

Corporate culture refers to the shared values, attitudes, standards, and beliefs that characterize members of an organization and define its nature. Corporate culture is rooted in an organization's goals, strategies, structure, and approaches to labour, customers, investors, and the greater community. As such, it is an essential component in any business's ultimate success or failure. Closely related concepts are corporate ethics which formally state the company's values and corporate image which is the public perception of the corporate culture. ${ }^{1}$ Corporate culture refers to the beliefs and behaviours that determine how a company's employees and management interact and handle outside business transactions. Often, corporate culture is implied, not expressly defined, and develops organically over time from the cumulative traits of the people the company hires. A company's culture will be reflected in its dress code, business hours, office setup, employee benefits, turnover, hiring decisions, treatment of clients, client satisfaction and every other aspect of operations.

\section{HISTORY OF CORPORATE CULTURE}

Consciousness of corporate or hierarchical culture in organizations and different associations, for example, colleges developed in the 1960s. The term corporate culture created in the mid 1980s and turned out to be broadly known by the 1990s. Corporate culture was utilized amid those periods by chiefs, sociologists and

\footnotetext{
${ }^{1}$ Corporate culture, Investopedia, Date- 11/07/2018, Time12:20am, available at-
}

https://www.investopedia.com/terms/c/corporate-culture.asp 
different scholastics to portray the character of an organization. This included summed up convictions and practices, far reaching esteem frameworks, administration methodologies, worker correspondence and relations, workplace and mentality. Corporate culture would go ahead to incorporate organization starting point fantasies by means of magnetic CEOs, and also visual images, for example, logos and trademarks.

By 2015, corporate culture was not just made by the authors, administration and representatives of an organization, yet in addition impacted by national societies and conventions, financial patterns, global exchange, organization size and items.

There are an assortment of terms that identify with organizations influenced by various societies, particularly in the wake of globalization and the expanded worldwide communication of the present business condition. In that capacity, the term cross culture alludes to "the connection of individuals from various foundations in the business world"; culture stun alludes to the disarray or uneasiness individuals encounter when directing business in a general public other than their own; and invert culture stun is frequently experienced by individuals who spend extensive circumstances abroad for business and experience issues correcting upon their arrival. To make positive cross-culture encounters and encourage a more strong and profitable corporate culture, organizations regularly give top to bottom assets to battling the event of the above, including particular preparing that enhances cross-culture business associations.

When a company enters a new market, there are various problems it might encounter, such as, cultural differences. The whole concept regarding culture is quite wide and rather hard to comprehend. Companies have to take cultural differences into consideration, differences like; languages, religions, social standards and demographics. If the company has the information and knowledge it needs, the entering process and the cultural shock will be less painful. Mode of entry is also a vital matter for companies, for example what mode of entry is the best to use for the chosen market, and how to combine the mode of entry process with cultural differences. Previous research have been done in the fields of emerging markets, culture, marketing, as well as mode of entry, by authors like Geert Hofstede, SvendHollensen (2007),
Charles Jonscher and Ashley Summerfield (1994) in addition to several others.

\section{ORGANISATIONAL CULTURE}

Organizational culture is defined as the underlying beliefs, assumptions, values and ways of interacting that contribute to the unique social and psychological environment of an organization. Organizational culture includes an organization's expectations, experiences, philosophy, as well as the values that guide member behaviour, and is expressed in member self-image, inner workings, interactions with the outside world, and future expectations. Culture is based on shared attitudes, beliefs, customs, and written and unwritten rules that have been developed over time and are considered valid (The Business Dictionary).Culture also includes the organization's vision, values, norms, systems, symbols, language, assumptions, beliefs, and habits (Needle, 2004).

${ }^{2}$ Organizational culture represents an company's common beliefs and concepts that create the social and psychological environment of an organization. In the contemporary business environment, the company culture often contributes to its success, as it is unique and it cannot be transferred to competitors. It can also contribute to its failure. Based on corporate culture, members know how they should perform their jobs, behave, and dress.

Furthermore, culture dictates the freedom of participation in the managerial decision-making. A strong culture has a strong influence on organizational members and creates committed employees by instilling clear cultural values and beliefs. A weak culture can breed apathy, resentment, and unproductive workers.

A great example of strong organizational culture is Toyota. By introducing the "Toyota Way", the company has managed to create a unique corporate culture, which respects all organizational members, supports teamwork, stimulate personal and organizational growth and instils a long-term vision to meet organizational challenges. The "Toyota Way" encompasses the Vision, the Target, the Practical Application, the Testing, the Dialogue and the Place to inspire the manufacturing of Toyota vehicles.

\footnotetext{
${ }^{2}$ What is organisational culture, my accounting course, Date11/07/2018, Time- 12:52am, available at-

https://www.myaccountingcourse.com/accountingdictionary/organizational-culture
} 
All the values and methods recommended by the "Toyota Way" reflect continuous improvement and respect for people. Toyota bases its corporate culture on the principle of Ideal Pragmatism, i.e. the right to pursue two contradictory perspectives through a dialectical method that leads an organization to overcome its limitations and seek for the best organizational results. Thus, through the implementation of "both and more" principle, the company seeks the ideas and suggestions of respectful organizational members that add value to the organization.

The example of Toyota proves that when the organizational culture is appropriate, it can act as a competitive advantage and a fundamental reason for business success. Conversely, when it is inappropriate, it serves as a competitive disadvantage and causes failure. A good example of this is the toxic culture that led to the demise of Enron

\section{EMERGENCE OF CORPORATE CULTURE}

The idea of corporate culture rose as an intentionally developed reality in the 1960 s close by related advancements like the social duty developmentitself the outcome of environmentalism, consumerism, and open antagonistic vibe to multinationals. Familiarity with corporate culture was without a doubt additionally a result of development, not slightest extension abroad-where partnerships wound up contending in other national societies. The U.S. rivalry with Japan, with its special corporate culture, was yet another impact. So was the ascent to noticeable quality of administration masters the senior member of whom was Peter Drucker. As partnerships wound up mindful of themselves as performers on the social scene, corporate culture turned out to be yet another part of the business to watch and to assessnearby the "hard" measures of benefits, incomes, benefits, and investor return.

Corporate culture by definition influences a company's tasks. It is likewise, by definition, something that streams from administration descending and outward. In numerous organizations, the "way of life" was set right off the bat by the appealling movement and administration of an author. In any case, as significant propensities turn out to be profoundly systematized, corporate culture likewise turns into an institutional propensity that newcomers obtain. In real work on "reevaluating" the organization starting from the top, along these lines, is hard to accomplish, requires significant investment, and happens just under solid initiative.

Spectators and examiners of the wonder have a tendency to subdivide culture into its different articulations related either to significant supporters (representatives and laborers, clients, merchants, government, the network) or to techniques or styles of task (mindful, preservationist, chance taking, forceful, inventive). A corporate culture may likewise, by violating certain limits, end up self-destructive-as the instance of Enron Corporation, the vitality merchant, represents. In the Enron culture a forceful, inventive, high-hazard style prompted misrepresentation and extreme crumple. Investigation is useful in seeing how a corporate culture conveys what needs be in particular territories. Be that as it may, the idea is social and culture, as the expression itself infers. It doesn't fit revamping by an adjustment of standard building squares.

\section{CHARACTERISTICS OF CORPORATE CULTURE}

The advantages of a solid corporate culture are both instinctive and bolstered by sociology. As per James L. Heskett, culture "can represent $20-30 \%$ of the differential in corporate execution when contrasted and 'socially unremarkable' contenders." And HBR scholars have offered counsel on exploring diverse geographic societies, choosing employments in light of culture, evolving societies, and offering input crosswise over societies, among different themes.

${ }^{3}$ Each culture is unique and myriad factors go into creating one, but I've observed at least six common components of great cultures. Isolating those elements can be the first step to building a differentiated culture and a lasting organization.

1. Vision: A great culture starts with a vision or mission statement. These simple turns of phrase guide a company's values and provide it with purpose. That purpose, in turn, orients every decision employees make. When they are deeply authentic and prominently displayed, good vision statements can even help orient customers, suppliers, and other stakeholders. Nonprofits often excel at having compelling, simple vision statements. The Alzheimer's Association, for example, is dedicated to "a world without

\footnotetext{
${ }^{3}$ Six components of great corporate culture, Harvard Business Review Press, Date- 18/07/2018, Time- 4:38pm, available athttps://hbr.org/2013/05/six-components-of-culture
} 
Alzheimer's." And Oxfam envisions "a just world without poverty." A vision statement is a simple but foundational element of culture.

2. Values: A company's values are the core of its culture. While a vision articulates a company's purpose, values offer a set of guidelines on the behaviors and mindsets needed to achieve that vision. McKinsey \& Company, for example, has a clearly articulated set of values that are prominently communicated to all employees and involve the way that firm vows to serve clients, treat colleagues, and uphold professional standards. Google's values might be best articulated by their famous phrase, "Don't be evil." But they are also enshrined in their "ten things we know to be true." And while many companies find their values revolve around a few simple topics (employees, clients, professionalism, etc.), the originality of those values is less important than their authenticity.

3. Practices: Of course, values are of little importance unless they are enshrined in a company's practices. If an organization professès, "people are our greatest asset," it should also be ready to invest in people in visible ways. Wegman's, for example, heralds values like "caring" and "respect," promising prospects "a job [they'll] love." And it follows through in its company practices, ranked by Fortune as the fifth best company to work for. Similarly, if an organization values "flat" hierarchy, it must encourage more junior team members to dissent in discussions without fear or negative repercussions. And whatever an organization's values, they must be reinforced in review criteria and promotion policies, and baked into the operating principles of daily life in the firm.

4. People: No company can build a coherent culture without people who either share its core values or possess the willingness and ability to embrace those values. That's why the greatest firms in the world also have some of the most stringent recruiting policies. According to Charles Ellis, as noted in a recent review of his book what it Take: Seven Secrets of Success from the World's Greatest Professional Firms, the best firms are "fanatical about recruiting new employees who are not just the most talented but also the best suited to a particular corporate culture." Ellis highlights that those firms often have 8-20 people interview each candidate. And as an added benefit, Steven Hunt notes at Monster.com that one study found applicants who were a cultural fit would accept a 7\% lower salary, and departments with cultural alignment had $30 \%$ less turnover. People stick with cultures they like, and bringing on the right "culture carriers" reinforces the culture an organization already has.

5. Narrative: Marshall Ganz was once a key part of Caesar Chavez's United Farm Workers movement and helped structure the organizing platform for Barack Obama's 2008 presidential campaign. Now a professor at Harvard, one of Ganz's core areas of research and teaching is the power of narrative. Any organization has a unique history - a unique story. And the ability to unearth that history and craft it into a narrative is a core element of culture creation. The elements of that narrative can be formal - like Coca-Cola, which dedicated an enormous resource to celebrating its heritage and even has a World of Coke museum in Atlanta - or informal, like those stories about how Steve Jobs' early fascination with calligraphy shaped the aesthetically oriented culture at Apple. But they are more powerful when identified, shaped, and retold as a part of a firm's ongoing culture.

6. Place: Why does Pixar have a huge open atrium engineering an environment where firm members run into each other throughout the day and interact in informal, unplanned ways? Why does Mayor Michael Bloomberg prefer his staff sit in a "bullpen" environment, rather than one of separate offices with soundproof doors? And why do tech firms cluster in Silicon Valley and financial firms cluster in London and New York? There are obviously numerous answers to each of these questions, but one clear answer is that place shapes culture. Open architecture is more conducive to certain office behaviors, like collaboration. Certain cities and countries have local cultures that may reinforce or contradict the culture a firm is trying to create. Place - whether geography, architecture, or aesthetic design impacts the values and behaviours of people in a workplace.

There are other factors that influence culture. But these six components can provide a firm foundation for shaping a new organization's culture. And 
identifying and understanding them more fully in an existing organization can be the first step to revitalizing or reshaping culture in a company looking for change.

\section{CORPORATE CULTURE IN SMALL BUSINESS}

Every small business, even those with just a bunch of workers, can profit by developing a corporate culture that keeps individuals drew in and beneficial while enhancing business execution. In any case, making an extraordinary corporate culture isn't the kind of venture that can be proficient inside a particular day and age. Small business leaders need to deliberately plant seeds and invest predictable exertion. After some time, these effortscan encourage the propensities and qualities they need their staff to grasp.

${ }^{4}$ Corporate culture should convey how the business sets expectations and rewards desired behaviours. These definitions can be established within a mission statement, the business goals, the brand strategy and even a company logo.

Across all departments, from accounting and finance to operations, sales and marketing, corporate culture plays a vital role in the success of a small business. Corporate culture can have a direct impact on hiring, employee retention, collaboration, policy compliance and communication, as well as the effectiveness of change management.

Maintaining a positive, vibrant working climate can help small businesses to weather economic downturns, staffing and technology changes, and shifts in the marketplace.

One way that small business leaders can help maintain a positive corporate culture is by including all members of the company when communicating shortand long-term company goals. Employees who clearly understand their company's strategic objectives will be more motivated to help the company achieve them. Managers should go beyond simply sharing the vision, however. They also need to show their workers how their contributions support efforts to reach organizational goals. Even startups and other fast-growing businesses still refining their vision

\footnotetext{
${ }^{4}$ Robert Half, The Role of Corporate culture in small business, The Robert Half Blog, Date- 19/07/2018, Time- 2:09pm, available at- https://www.roberthalf.com/blog/managementtips/the-role-of-corporate-culture-in-small-business
}

should communicate their initial business objectives to employees, and continually update staff members on progress toward achieving those goals.

This strategy can also help to improve retention: When employees understand how they specifically make a difference in the organization, they are more likely to feel valued.

$>$ A solid hierarchical culture can help give representatives bearing. It fills in as a compass for hierarchical activity and can help direct representatives on the best way to carry on with partners, clients and administration.

$>$ A very much characterized hierarchical culture can enable you to separate your organization from its rivals.

A strong authoritative culture can prompt expanded dedication among workers and decreased turnover.

\section{EFFECT OF GLOBALIZATION ON CORPORATE CULTURE}

${ }^{5}$ The organizational culture is a complex set of ideologies, norms of behaviour, attitudes, opinions, symbols and core values shared throughout the organization, affecting the way the organization meet sits objectives, and certainly helping the regulation and control of employee conduct. It more often than not happens in the procedure of taking care of the issues looked by the association amid its work. These issues definitely happen and suggest conversation starters that are related with outside adjustment and inward reconciliation. The outside adjustment emerges because of the fast changes happening in the earth, along these lines the association is attempting to discover its place in the condition, and to look after its aggressiveness in the long haul. Clearly, the association needs to discover instruments which will hold its conservativeness, which will give more prominent operational efficiencies and accomplish the set objectives.

Supervisors likewise have a functioning part in molding the authoritative culture both with their identity and the administration they apply. Their effect on authoritative culture is twofold, in a roundabout way, through their conduct and the

\footnotetext{
${ }^{5}$ Ass. Prof. Lidija Stefanovska and Ass. Prof. Marjan

Tanushevski, The impact of globalization on Organisational Culture, Indian Journal of Commerce and Management studies, Date- 20/07/2018, Time- 7:02pm, available athttp://www.scholarshub.net/ijcms/vol7/issue3/Paper_01.pdf
} 
standards of administration for which they are doled out. Giving their own particular case, they make an interior situation that supports the advancement of a particular authoritative culture. The impact of chiefs can be immediate too, cognizant furthermore, consider, planned to impact the improvement of hierarchical culture and to help the work targets and the technique of the association. In this persuasive factor it is especially critical to specify the identity of the pioneer of the association, which is the focal figure and accordingly is in a situation to force its perspectives and convictions.

${ }^{6}$ The full effect of globalization in the work environment still can't seem to be acknowledged, however as more organizations grasp this pattern and turn out to be more various, certain progressions are developing. While a considerable lot of these progressions are great, others may not be as positive. Entrepreneurs are discovering that they need to embrace new arrangements and new rules to stay aware of these progressions.

\section{Expanded Cultural Diversity}

As globalization turns out to be more predominant, organizations manage expanded social assorted variety inside the workforce. These progressions require little and vast organizations receive new arrangements and rules for specialists. This expanded social decent variety additionally has delivered numerous advantages as organizations increase new bits of knowledge into various societies from an administration and a showcasing stance.

\section{$>$ Income Changes}

Influenced numerous laborers as more organizations approach abroad organizations that offer outsourcing, compensation have changed for some laborers. With bring down ways of life, third world organizations can offer their administrations at a rate incredibly lessened from those in nations with higher expectations for everyday comforts. This has in the United States and in addition other vast nations as more organizations grasp the outsourcing pattern. While it implies a more prominent net revenue for the organizations, it can likewise prompt lessened winning potential for workers.

\footnotetext{
${ }^{6}$ Kate mcfarlin, Effect of Globalization in the workplace, Chron, Date- 20/07/2018, Time- 7:50pm, available at-

https://smallbusiness.chron.com/effects-globalization-workplace10738.html
}

$>$ Worker Training

Social, religious and ethnic assorted variety in the working environment exhibits a requirement for more representatives preparing. So as to ensure their organizations and their new representatives from separation, administrators have needed to actualize arrangements and offer preparing to existing workers to ensure everybody can acknowledge each other. This has prompted a more prominent energy about different societies and perspectives in a few organizations, while disturbing a few representatives who lean toward a less socially assorted workplace.

\section{$>$ Expanded Standards}

Organizations in outside nations, especially in the third world, have needed to receive a more Western standard regarding giving better work environment wellbeing and expanding work environment condition norms. This specifically benefits the representatives who may have been beforehand working in hazardous or unsanitary conditions. While conditions still stay poor in a few regions, an expansion in worry over laborer wellbeing is clear, especially in bigger organizations. Also, worries over youngster work has enhanced the conditions for youthful laborers in these poorer nations.

\section{Employment Losses}

As more items end up accessible at bring down costs from directs showcases less of similar items are being sold by U.S. organizations. Lower request has prompted diminishes in assembling, which thusly has brought about assembling work misfortunes no matter how you look at it. A significant part of the misfortune has been a consequence of expanded exchange with China. Markets that have been particularly influenced have been makers of gadgets, materials, attire and furniture.

There are pros and cons to globalization as they pertain to companies:

\section{PROS:}

$>$ Decent variety loans to strength- Organizations that go worldwide and employ individuals from various foundations will have systems of individuals that take care of issues in an unexpected way. On the off chance that an organization can position itself to augment on that appropriated comprehension, showcase stuns, administrative activities, or different fortunate spots of destiny can be moved around. 
Nearsightedness must be limited- Another romanticizing, however it remains as sensible that incorporated associations expand the points of view of its workers. In the event that your group has people from all finished, people will be looked with the decision to refresh their suppositions on the world or hazard out of date quality, confinement, or even end.

\section{CONS:}

$>$ Reconciliation is certifiably not a smooth procedure- People are seemingly hardwired to make sense of companion or enemy quickly and "companions" are simpler to make when an individual looks, acts, and conveys like you. Culture conflicts in administration are plenteous as various foundations and narratives contend to stay significant.

> The Morality Problem- The inquiries of "wrong" and "right" can be extended past their viable utilize when two legitimate contending understandings interface. Complex identifiers like race, religion, or financial position regularly call for differed, however worthy reactions in social communication. Somebody from Mecca may feel its nonnegotiable to ask five times each day and profoundly disrupt somebody from Mobile. Nor aren't right nor are correct, they are essentially following the strictures of their particular encounters.

\section{DIFFERENCE BETWEEN MARKETS OF DIFFERENT COUNTRIES}

${ }^{7}$ Market access refers to the ability of a company or country to sell goods and services across borders. Market access can be used to refer to domestic trade as well as international trade although the latter is the most common context. Market access is not the same as free trade. The ability to sell in a market is often accompanied by tariffs, duties or even quotas, whereas free trade implies that goods and services flow across the borders without any extra costs imposed by governments. Even so, market access is seen as an early step towards deepening trade ties. Market access is increasingly the stated goal of trade negotiations as opposed to true free trade.

International trade includes complex transaction between at least two governments. All through these

\footnotetext{
${ }^{7}$ Market access, Investopedia, Date- 22/07/2018, Time- 2:03am, available at- https://www.investopedia.com/terms $/ \mathrm{m} /$ marketaccess.asp
}

arrangements, members ordinarily push for showcase get to that supports their specific fare ventures while likewise endeavouring to restrict advertise access to import items that could conceivably contend with touchy or politically vital household enterprises. Market get to is viewed as unmistakable from organized commerce in light of the fact that the procedure of arrangement is gone for helpful exchange that may not really be more liberated exchange.

This give and take process describes worldwide exchange arrangements today and clarifies why most transactions look for more market get to instead of more liberated exchange. Following quite a while of expanding worldwide exchange, there is prove that vast swaths of individuals never again bolster generally organized commerce because of worries over residential employer stability. The United States, quite a while defender of more liberated worldwide exchange, has seen an expansion openly doubt of facilitated commerce in conjunction with the fast development of its exchanging accomplices' economies, especially Mexico and China. Be that as it may, the greater part of individuals still need the advantages of worldwide exchange, for example, a wide assortment of intensely valued merchandise and a solid fare showcase for locally delivered items.

Regardless of the negative open conclusion towards worldwide exchange, it has reliably been the driver of general worldwide riches in spite of the fact that the riches isn't similarly circulated. To keep away from negative meanings, exchange bargains are currently talked about as far as market get to instead of facilitated commerce. This is wit to some degree in light of the fact that a significant number of similar points are being met, and exchange ties normally develop after some time due to the net pick up for the economies included. Strangely, worldwide exchange as a term is being pushed out for global business.

Contrary to conventional wisdom, market access barriers faced by developing country exporters are not decreasing for some of their most important export sectors. LDCs are especially at risk. ${ }^{8}$ The common perception in developed market economies is that we

\footnotetext{
${ }^{8}$ Market Access Barriers: A Growing Issue for Developing Country Exporters?, International Trade Forum Magazine, Date22/07/2018, Time- 2:21 am, available at-

http://www.tradeforum.org/Market-Access-Barriers-A-GrowingIssue-for-Developing-Country-Exporters/
} 
live in a globalized world where trade barriers for developing countries have all but disappeared. The Doha Development Agenda, recent bilateral and regional agreements and voluntary reductions in trade barriers favoring least developed and developing countries are seen as having significantly enhanced market access. Developed market economies have taken steps to improve market access for developing countries. They have expanded preferential access for goods from developing countries and reduced tariffs on goods of interest to developing countries.

Three obstacles are hindering the track to better market get to. To start with, particular taxes are broad. They are less straightforward than customary (advertisement valorem) duties and they have a tendency to oppress creating nations. Second, product costs have dove. On the off chance that taxes were advertisement valorem (a level of aggregate esteem), the obligations really paid would have declined with the costs. Since particular taxes are so imperative particularly for products - by and by, creating nations and slightest created nations (LDCs) are seeing a viable ascent in assurance. In addition, the offer of LDC trades with obligation free access is diminishing. Third, non-levy hindrances (nourishment wellbeing measures, ecological accreditation, and so forth.) are developing; on account of LDCs, they are especially sensational.

\section{SPECIFIC TARRIF}

Most nations collect taxes in promotion valorem terms - as a level of an item's aggregate esteem. Be that as it may, a few nations utilize particular levies. This has been particularly the case for farming items, which stay significant fares for creating nations and LDCs specifically. The explanation behind this is amid the Uruguay Round nations consented to change over shares (quantitative confinements) and variable duties for rural items into levies.

\section{FALLING COMMODITY PRICES}

Commodities prices are as of now at their most reduced level since the mid-1990s. All ware gatherings (aside from petroleum) saw costs fall altogether. So notwithstanding when nations diminish particular levies, this may not convert into bring down hindrances, if costs are falling quicker.

\section{NON TARIFF BARRIERS}

Quantifiable levy obstructions aren't the main obstacle for creating nation sends out. An ongoing ITC contemplate demonstrates that LDCs are the most presented to non-duty boundaries. Illustrations incorporate plant and creature wellbeing measures, sustenance security norms, ecological confirmation and other such fare quality principles.

LDCs and developing countries face surprising market access barriers in OECD countries for agriculture, textiles and clothing exports. Below are protection levels for the period 1996-2001. The calculations are based on ad valorem tariffs and specific tariffs (translated into ad valorem equivalents). The overall levels have not declined significantly contrary to Urugay Round expectations. In some cases (textiles and clothing for LDCs) they have actually increased.

\section{INDIA-CHINA MARKET ACCESS AND TRADE RELATIONS}

India China exchange relations are the most essential piece of reciprocal relations amongst India and China. From a transitory decrease in the inundation of Chinese imports in the Indian markets, the situation appears to have changed - India is getting a charge out of a positive adjust of exchange with China. The India China exchange relations are controlled by the India China JBC, which guarantees a free trade of items and administrations between the two countries.

The essential things of Indian fares to China are minerals, slag and fiery debris, iron and steel, plastics, natural synthetic concoctions, and cotton. To expand the degree of sending out Indian merchandise to China, be that as it may, there ought to be an extraordinary accentuation on speculations and exchange administrations and information based divisions. ${ }^{9}$ The other potential things of exchange amongst India and China are marine items, oil seeds, salt, inorganic synthetic compounds, plastic, elastic, optical and medicinal hardware, and dairy items. Extraordinary potential likewise exists in zones like biotechnology, IT and ITES, wellbeing, training, tourism, and budgetary segment.

\footnotetext{
${ }^{9}$ India china trade relation, Maps of India, Date- 22/07/2018, Time- 3:30am, available at-

https://business.mapsofindia.com/trade-relations/india-china/
} 
The fundamental things that contain Chinese fares to India are electrical hardware and gear, concrete, natural synthetic substances, atomic reactors, boilers, apparatus, silk, mineral powers, and oils. Esteem included things like electrical hardware rules Chinese fares to India. This displays Chinese fares to India are genuinely enhanced and incorporates asset based items, made things, and low and medium innovation items. It is said that if India is to catch the business sectors of China and appreciate benefits, at that point it would need to find new stock and branch out its fares to China.

In 2004, the Chinese fares to India remained at US\$ 5926.67 million. Be that as it may, it industrialists in India were not for China being sans given access to the household markets. However, respective exchange relations amongst India and China have expanded throughout the years, achieving US\$18.7 billion of every 2005 from US $\$ 4.8$ billion out of 2002 . Be that as it may, the reciprocal exchange is to be expanded further to US\$ 20 billion by 2008 and further to US $\$ 30$ billion by 2010 .

The primary things to be sent out from China to India are electrical apparatus and gear, natural synthetics, atomic reactors, boilers, hardware, silk, mineral powers, and oils. Esteem included things additionally overwhelm Chinese fares to India, similar to hardware, exceptionally electrical apparatus, which shapes around $36 \%$ of Chinese fares.

\section{Late improvements with respect to Chinese Exports to India}

$>$ Before all else, Chinese firms were excited about sending out shoddy electronic things, articles of clothing, and toys to the Indian markets. Be that as it may, as of late, Chinese exporters have been concentrating on the bond showcase. Two Chinese bond organizations, Yingde Dragon Mountain cement organization Ltd. what's more, Longkou Fanlin Cement Company have been approved to offer concrete in Indian market. The purposes for the sudden enthusiasm of the Chinese bond organizations in entering the Indian market are that China is the world's biggest concrete maker and that the per capita concrete utilization is generally low in India - around 150 kilogram for each annum, short of what 33\% of China's for every capita utilization, as in 2006. An Ahmadabad-based material organization is going about as the neighbourhood specialist of the Chinese firms in India.

$>$ The prospects for Chinese fares to India have been upgraded from 2006, with the opening of the imminent Indo China fringe exchange. Exchange has been started between Tibet, an independent area of China, and India through Nathu La Pass, revived following 44 years. From that point onwards, about 15 things are being traded from China to India.

\section{IS IT PROFITABLE FOR A COUNTRY TO ALLOW FOREIGN MARKET ACCESS}

Access to remote and local markets can furnish inventive organizations with learning openings and with items and administrations that help their development forms. Enhanced access to remote markets may likewise expand the market measure and the execution of imaginative organizations. Confirmation affirms the constructive outcome of access to outside and local markets on imaginative firms. However how much markets are open contrasts crosswise over nations. Access to outside and local markets can be encouraged by vagrants. Access to fund and business bolster foundation are regularly basic in getting to outside business sectors. A few arrangements, including lessening tax and non-tax obstructions and offering help to enter remote markets, can help imaginative organizations.

Yes, it can be said that allowing foreign market access can be profitable for the country, as we are living in the era of globalization; through foreign market access we are able to understand the other country's culture. Corporate culture plays a very crucial role in foreign market access as the MNCs helps bring market access of countries. Foreign market access expands the area of business and variety and choices for the consumer. But foreign market access should be limited so that country's own market doesn't go down because of competition with the foreign market. As every coin has two sides, it can be said that foreign market access is profitable but it should in a limit. 